\title{
Work Safety in slaughterhouses: general aspects
}

\author{
Segurança do Trabalho em frigoríficos: aspectos gerais \\ Seguridad em el Trabajo em mataderos: aspectos generales
}

\section{Abstract}

This study aimed at carrying out the characteristics existing in slaughterhouses work scenarios, taking into account the aspects that corroborate to ensure employees' health conditions, such as physical, chemical, biological risks, and, mainly, ergonomic. It is noted that the slaughterhouses have several changes that compromise the physical conditions of those who provide practical actions in these service spaces. The data from this research are seasoned due to issues involving ergonomic aspects such as Work-Related Musculoskeletal Disorders (WRMD) and temperature, humidity, risky materials, noise, extensive workloads, among other factors that compromise, significantly, the health of employees. In short, the scenarios lack changes and improvements in conditions of caring for the well-being of employees, as well as envisioning the need to ensure conditions for improving their materials, proposing a complementation in the training of their workers.

Keywords: Work conditions; Safety; Employee health.

\section{Resumo}

Este estudo objetivou realizar uma revisão das características existentes nos cenários de trabalho dos frigoríficos, levando em consideração os aspectos que corroboram para garantir as condições de saúde dos trabalhadores, tais como os riscos físicos, químicos, biológicos e, principalmente, ergonômicos. Observa-se que os frigoríficos apresentam diversas alterações que comprometem as condições físicas de quem realiza ações práticas nesses espaços de atendimento. Os dados da pesquisa são sazonais, devido a questões que envolvem aspectos ergonômicos, como Distúrbios Osteomusculares Relacionados ao Trabalho (DORT), além de temperatura, umidade, materiais de risco, ruídos, cargas de trabalho extensas, entre outros fatores que comprometem significativamente a saúde dos funcionários. Em suma, os cenários carecem de mudanças e melhorias nas condições de cuidado ao bem-estar dos funcionários, bem como vislumbram a necessidade de garantir condições para o aprimoramento de seus materiais, propondo um complemento na formação de seus funcionários.

Palavras-chave: Condições de trabalho; Segurança; Saúde dos funcionários.

\section{Resumen}

Este estudio tuvo como objetivo realizar una revisión de las características existentes en los escenarios de trabajo de los mataderos, teniendo en cuenta los aspectos que corroboran para otorgar las condiciones de salud de los trabajadores, como los riesgos físicos, químicos, biológicos y, especialmente, ergonómicos. Se observa que los mataderos tienen varios cambios que comprometen las condiciones físicas de quienes realizan acciones prácticas en estos espacios de 
servicio. Los datos de la investigación son estacionales, debido a cuestiones que involucran aspectos ergonómicos, como Trastornos Musculoesqueléticos Relacionados con el Trabajo (TMRT), así como temperatura, humedad, materiales de riesgo, ruido, cargas de trabajo extensas, entre otros factores que comprometen significativamente la salud. de los empleados. En definitiva, los escenarios carecen de cambios y mejoras en las condiciones de atención para el bienestar de los empleados, así como vislumbran la necesidad de garantizar condiciones para la mejora de sus materiales, proponiendo un complemento en la formación de sus empleados.

Palabras clave: Condiciones laborales; Seguridad; Salud de los empleados.

\section{Introduction}

Many working conditions, especially those that influence workers within the organization, such as the environment, hours and jobs, the task, the organization, the remuneration, food, well-being, among other conditions, have been reasons for concern on the part of organizations and social security and supervisory bodies (Evangelista, 2011). When it comes to work carried out in food production and processing centers and specifically in the meat industry, that is, in slaughterhouses, exposure to biological agents occurs as a result of the probable presence of microorganisms in the animal, in its products, and the work environment (Melamed et al., 2004).

The primary damages to workers' health resulting from work in the meat industry are infectious or parasitic diseases transmitted to man by animals and/or their products or carcasses, known as zoonoses (tuberculosis, brucellosis, etc.) (Rodrigues, 2018). Besides, respiratory disorders, allergies, and eczema are frequent. Many of these pathologies are recognized as occupational diseases but are rarely reported and registered as such or are not even related to work (Rocha, 2002).

In these environments, musculoskeletal diseases such as Repetitive Strain Injuries (RSI) and Work-Related Musculoskeletal Disorders (WRMD) are also common, according to Gandon, Ferraz, Pavan and Zaions (2017). There are also physical risks such as noise and cold, and chemical risks such as the contamination of organic and inorganic, natural or synthetic substances during meat processing, which cannot be overlooked (Matias \& Abib, 2007).

This study was based on a bibliographic review of the characteristics existing in slaughterhouses work scenarios, considering the aspects to ensure employees proper health conditions.

\section{Methodology}

The present study relies on a bibliographic research (Lima et al., 2020) from an exploratory and qualitative nature (Costa, A. \& Von Humboldt, 2020). A bibliographic survey was carried out by consulting works in international circulation databases (ScienceDirect, Scopus, Medline, and Google Scholar). The following keywords were used together or combined differently: ("workplace safety") AND ("slaughterhouses") AND ("occupation safety and health").

\section{Results and Discussion}

\subsection{Illness at work: the importance of prevention}

The word 'work' comes from the Latin tripalium (instrument of torture) and labor (pain, suffering). Over time, work has ceased to be seen as punishment and has come to be a vocation, profitable, and money producer. Work is the means of producing the necessary elements for the biological and social life of human beings, as well as intellectual, cultural, and affective life. Work provides people with the opportunity to feel useful, be a part of society, and have dignity (Matias \& Abib, 2007).

The working environment is the physical space determined by the establishment where the service is provided, and the entire route used to be in the employer's physical location, as well as other occasional places where the worker is displaced to execute activities. Article 6 of the CLT (Consolidação das Leis de Trabalho) does not distinguish between work performed at the employee's establishment and performed at the employee's home. According to Rocha (2002), the work environment includes all elements and conditions, including values and behaviors related to it which influence the workers physical and mental health. 
According to Abrahão and Pinho, workplace changes due to technological advancement allow a new perspective to analyze the relationship between man and work within the labor context and the consequences of the activity on workers and production. Thus, it is impossible to achieve life quality without quality at work because human beings spend most of their time within the work environment, which defines one's lifestyle, physical and intellectual health. To promote the worker's well-being is, first of all, to make him or her work in a clean, safe and healthy place. Thus, it is essential to safeguard the laborer, away from the countless forms of environmental degradation in their workplace, to perform their duty with better physical and mental integrity.

Within the work environment, two types of injuries are common: non-accidental injury and accidental injury. The nonaccidental injury arises from everyday activities, where the body overloads itself, staying in the same position for an extended time. In this situation, repetitive movements and fatigue are the major contributors to these injuries. On the other hand, the accidental injury results from an unexpected event that triggers an injury during work activity. These accidents can affect the neck, back, and other joints, causing muscle tension (Melamed et al., 2004). This suffering can also be caused when the worker is prevented from exercising his work freely when his or her creativity is blocked. At the same time, there are demands from multipurpose workers, educated and with initiative, and, in most cases, there is no opening for them to decide on the means and ends of their work process (Assunção, 2003).

According to Matias and Abib (2007), feelings of fear, helplessness, and frustration arise when the worker does not have the freedom to improve his work, and these feelings can have physical or somatic decompensations and diseases. Some workers start having feelings of uselessness, not realizing the importance and purpose of one's work; lack of dignity, that is, one perceives oneself to be just another "piece of gear", and disqualification, which ends up having a negative impact not only for the laborer but for the work environment as well (Cruz \& Lemos, 2005). Also, when there is no necessary recognition, other spaces in the daily lives of these workers end up being affected, and, therefore, work needs to be understood as something continuous, which extends beyond their space, influencing other parts of people's lives (Lancman \& Sznelwar, 2004).

This whole process leads to professional wear and tear, which according to Laurell and Noriega (1989), consists of the loss of sufficient and/or potential, biological and psychological capacity, that is, a set of bio psychic processes, and not a particular isolated process. Knowing the exhaustion process dynamics is of great importance, as it implies enabling necessary preventive measures for each type of work situation (Araújo, Sena, Viana, \& Araújo, 2005).

According to Rodrigues (2018), Brazil needs to go a long way for environmental protection at work to reach satisfactory minimum levels. In addition to the existing legislation, there is no business culture concerned and capable of adopting an effective health and safety management program. The number of accidents and occupational diseases in Brazil reflect the predominant culture in companies regarding Occupational Health and Safety (OHS). On the one hand, there is a tendency for medium and large companies to consider health, safety, and quality of life measures for workers as an often unnecessary expense; on the other hand, the direction of small companies tends to consider that the adoption of security measures are "a matter" of large and medium-sized companies. Consequently, there is a lack of perception of how advantageous it is to invest in OHS, hindering the development of a preventive culture (Másculo \& Vidal, 2013).

For a long time, it was accepted that the ratio between insured and uninsured costs was 1: 4. In Brazil, Social Security raises and disposes of approximately $\mathrm{R} \$ 2.5$ billion per year with accidents at work, and companies bear an additional cost in the order of R \$ 10 billion. So, the precarious prevention of work risks costs Social Security and private companies R 12.5 billion per year (Rodrigues, 2018).

It is essential to prevent the harmful effects of working conditions and their influences on health, and prevention must always anticipate the occurrence of injuries, defined from the mapping of work risks, to make the worker aware of the importance of preserving health, a significant factor in general health, to diagnose specific or systemic injuries early related to the work 
environment. Thus, it is vital to look at ergonomics, which is the science of designing the workplace, considering the worker's capabilities and limitations. Poor workplace design leads to tired, frustrated workers and can cause them a great deal of pain. In these conditions, productivity falls since no one can be productive with pain and, consequently, the companies' revenues are not high (Wisner, 1994).

A process of improving systematic ergonomics removes the risk factors that lead to musculoskeletal injuries and allows the improvement of human performance and productivity (Saliba, 2018). An ergonomic improvement process can be a key factor for a company's competitiveness in the market and provides a better work experience for employees (Ranney, 2000).

\subsection{Slaughterhouse work and health risks}

Working in slaughterhouses presents a series of risks, both from accidents and occupational diseases (Mendes, Santos, \& Ichikawa, 2017). Therefore, companies in this sector must adopt measures to prevent and mitigate health risks (Vogel, Karltun, Eklund, \& Engkvist, 2013). The production areas of slaughterhouses have meat processing sectors (Marzoque et al., 2020), where the most significant risks to workers' health occur. There are different risks in these areas that can affect the employee's health in both the short and long term. Within this scenario, slaughterhouses must comply with the Occupational Health and Safety regulations established in Brazil, seeking to practice the necessary measures that contribute to maintaining and improving efficiency levels in operations and providing their workers with a safe working environment (Suárez, 2015).

\subsubsection{Physical risks}

Physical risks are all environmental physical factors that can cause adverse health effects, depending on their intensity, exposure, and concentration. The physical risks include conditions involving aspects related to sound, with high potencies of noise produced by machines that exude sound intensity chords, and exposure to low temperatures that lead to the preservation of food, among others (O'Sullivan \& Gallwey, 2005).

Noise is a pollutant that affects workers and is among the occupational and environmental factors that most affect operators' health and produces stress. The reaction capacity of workers is different in each type (Torres, 2002). Noise is a major health hazard, as it can alter the hearing capacity of workers in slaughterhouses (Suárez, 2015).

Another issue is the temperature inside the slaughterhouse, which can cause minimal discomfort to the employee, as it is a low temperature and high humidity space. A person is considered to be exposed to cold when the temperature and air velocity in his workplace is such that they produce a net loss of heat from his or her body, which can lower his or her temperature to $36^{\circ}$ C. In practice, this definition is not very useful; therefore, as a general rule, the risk of exposure to cold temperatures can be considered to exist in environments with temperatures below $10^{\circ} \mathrm{C}$ (Kilbom, 1994). The most important effect of cold on the human body is the loss of heat, with the consequent decrease in internal temperature, and there may be a reduction in concentration and logical reasoning, loss of manual dexterity, severe tremors, and hypothermia. Localized skin damage can also occur without freezing, such as perniosis (chilblains) and trenches. Also, respiratory disorders, allergies, and eczema are frequent. Many of these pathologies are recognized as occupational diseases but are rarely reported and registered as such (Torres, 2002). Symptoms of prolonged exposure to cold include irritation, redness, inflammation, and, in severe cases, possible skin ulceration on the cheeks, ears, and fingers. The ditch foot, also known as immersion foot, occurs due to prolonged exposure to wet and cold conditions (without freezing) and occurs mainly when the foot is constantly wet (Murcia \& Martinez, 2016).

To protect the worker from the general cooling of the body in cold rooms, the company must provide the worker with the appropriate clothes and limit the exposure time, depending on the working temperature (Torres, 2002).

Generally speaking, the worker's clothing should include three layers: an interior that should be soft, flexible, nonallergic and not retain moisture, but transmits it to the next layer; an intermediate layer, whose function is to capture cold air 
from outside and prevent it from reaching the skin; and an outer layer, which covers and protects the others and must be waterproof, breathable, windproof (in the case of drafts or when working outdoors) and resistant to the mechanical stresses and wear required by the type of work accomplished (Murcia \& Martinez, 2016).

Another issue to be observed is the preparation of clothing and personal protective equipment - PPE, which must be strictly required to prevent discomfort and accidents, examples of appropriate actions: use of gloves, thermal uniforms, protectors, glove shoes, everything to mitigate the impacts of thermal changes (Vogel et al., 2013).

\subsubsection{Chemical risks}

Chemical hazards include any organic and inorganic substance, natural or synthetic, that during manufacture, handling, transport, and storage or use can be incorporated into the ambient air as powders, vapors, or gases with irritating, corrosive, suffocating, or toxic effects and in quantities likely to harm the health of people who come in contact with them (Suárez, 2015). Given the physical space and environmental conditions of work in slaughterhouses, ammonia leaks in the refrigeration circuits are a significant risk because exposed people can suffer a little discomfort or severe poisoning, leading to death (Vogel et al., 2013). Besides, it should be borne in mind that the consequences can affect the factory employees and the people who live, study or work in the neighborhood (Murcia \& Martinez, 2016).

According to international statistics, about $70 \%$ of ammonia leaks in slaughterhouses are caused by failures in circuit components' integrity, while approximately 30\% are generated by human error (Murcia \& Martinez, 2016). In this sense, companies must have measures to prevent and mitigate leaks. In general, prevention measures should include training the personnel in charge of the system, preventive maintenance, safe work procedures; inspection plan; incorporation of safety valves in the system, and analysis of trends in its operational parameters. Concerning mitigating the consequences, it is advisable to have emergency ventilation, ammonia detectors with alarms; full-face self-contained breathing apparatus; trained emergency personnel, and emergency plan (Vogel et al., 2013).

Given the impact that ammonia spills usually have on workers' health, it is recommended to have a communication and coordination strategy with emergency authorities and institutions. Practices with the participation of these entities should help the company maintain control over the actions of the emergency plan and the information beyond the media in the event of a leak (Torres, 2002).

\subsubsection{Biological risks}

Biological hazards encompass all living agents, whether they are of animal or plant origin and all substances derived from there, found in the workplace, which may negatively affect workers' health. Adverse effects can organize infectious, toxic, or allergic processes (Vogel et al., 2013). Biological risks are classified as microorganisms that cause disease conditions if there is contact with humans.

Concerning work carried out in food production and processing centers and, specifically, in slaughterhouses, exposure to biological agents occurs due to microorganisms in the animal, its products, and the working environment (Murcia \& Martinez, 2016). Microorganisms, viruses, bacteria, parasites, protozoa, fungi, and bacilli are considered. Humid environments that involve aspects related to food are likely to cause such contamination situations.

Lachance et al. (2010) reported a subacute neurological syndrome that affected workers at two hog slaughterhouses in Minnesota and Indiana, United States. The neurological disorder described is autoimmune origin and is related to occupational exposure to various aerosolized porcine brain tissue antigens. The nerve involvement pattern suggests the nerve roots and vulnerability of the terminals where the blood-nerve barrier is permeable. 
The primary damage to workers' health resulting from work in slaughterhouses are infectious or parasitic diseases transmitted to humans by animals and/or their products or carcasses, known as zoonoses (tuberculosis, brucellosis, etc.) (Murcia \& Martinez, 2016). The meat of animals (cattle, pigs, fish, poultry) after slaughter is susceptible to attacks by microorganisms that attack tissues at room temperature. Also, in this case, keeping the meat at low temperatures, the deterioration process can be delayed and, thus, the meat can be consumed several months after slaughter (Vogel et al., 2013) in addition to having control over the acceptable manufacturing practices.

\subsubsection{Ergonomic risks}

Ergonomic risks are often seen in companies from different branches, especially those with contact with food aspects. These risks directly confront conditions related to the health of its employees, causing various symptoms and problems. In the deboning stage, the risks increase in the following aspects: physical, chemical, ergonomic, and accidental, with a demand for situations to be explored to minimize impacts on management.

The procedures performed in boning occur in continuous repetition, generating unnoticed tiredness since the employee starts to automate his methods to the way he or she feels familiar with the same movements. In his study, Barzotto (2013) proposes the exchange of functions between employees develop a greater perception of the actions developed.

Ergonomic damage is especially evident in the aspects of physical conditions to which employees are subjected, for example, to hours working while standing, without the possibility of rest. The high amount of weights to be handled due to the conditions that the animals present and the repeated actions developed at high intensity causing deplorable conditions of friction and risks (Murcia \& Martinez, 2016). In this sense, Work-Related Musculoskeletal Disorders (WRMD) are a well-documented health concern among workers worldwide (Vogel et al., 2013).

\subsection{Work-Related Musculoskeletal Disorders (WRMD)}

Previous research has identified an inadequate layout of the workspace and/or design of hand tools, which forces workers to adopt awkward postures for long periods as risk factors for the occurrence of WRMD. Therefore, it is essential that these risk factors, including inappropriate postures, repetitive movements, and forced efforts, are identified before workers develop WRMD, as they can result in decreased productivity and quality of work (Murcia \& Martinez, 2016). It was found that musculoskeletal disorders related to work are especially prevalent in unorganized occupational sectors since risk factors and control measures are less well understood in the informal economy.

According to Vogel et al. (2013), eight stages were identified in the manual meat cutting process, all of which required a significant amount of physical and/or cognitive effort. The first stage is sacrifice, in which the throat is cut, and blood is allowed to drain. More than physical effort, this step requires a significant amount of mental workload. The second stage is the separation of the head from the trunk, usually performed on the floor and requiring effort with the hands and maintaining a curved posture. However, the third stage is skinning, which consists of removing the animal's skin with a knife, a fact that requires precision. The fourth stage is to separate the skin into a single piece to maintain its value in the leather market by opening it to expose the viscera and, in the fifth stage, the organs are removed from the body. The sixth, seventh and eighth stages involve the removal of the animal's meat. Most buyers prefer boneless meat. This entire process requires manual labor, with strenuous activities and performed in inadequate postures, repetitive movements, and vigorous efforts with very little recovery time between movements. As can be seen, there are several ergonomic risk factors in the meat cutting sector, which can lead to the development of WRMD and affect productivity and quality of work. Risk factors are predominantly related to the limbs' inadequate postures and repetitive movements, accompanied by insufficient rest between activities. Studies have shown that most deboners' tasks involve awkward postures and repetitive activities, making the body vulnerable to WRMD and soft tissue injuries. The boners identified the back 
as the body's area most affected by discomfort due to performing tasks that require trunk flexion and torsion (Murcia \& Martinez, 2016).

Studies that verified the postural analysis of boning workers found that many of the postures associated with meat cutting tasks were of high risk and required immediate intervention to prevent and treat WRMD. Particularly vulnerable postures, such as forward flexion and abduction of the arm with the forearm supine or supine, can increase the chances of WRMD. Flexion and abduction in front of the arm stress the glenohumeral capsule and make it vulnerable to injury (O'Sullivan \& Gallwey, 2005).

It is known that repeated movements increase the chances of lateral epicondylitis, a pathology whose effective treatment is unknown (Mi et al., 2017). It occurs mainly due to static muscle load and divergent postures for long periods. Previous studies have found that these working conditions affect the quality of life, productivity, occupational health, and workers safety, increasing the risk of developing WRMD. These risk factors for WRMD also exist for tasks such as slaughtering, pricking, cutting, and peeling the skin.

Based on repetitions (number of hand movements per minute), three tasks are considered dangerous and vulnerable to injury: chopping, cutting and segregating, being chopping the most vulnerable, as it had a very high level with a high repetition rate. In the three tasks mentioned above, the forearm and wrist are mainly used and are therefore vulnerable to injury. Investigations in a controlled environment on the mathematical modeling of risk factors for WRMD in different joints of the upper and lower limbs and different pressure forces and forearm torques revealed that repetitive twists, forward push-ups, and even lifting light loads were factors significant. The genesis of WRMD and injuries, as well as inadequate postures, impose a tremendous amount of strength on the lumbosacral segment of the spine (Kilbom, 1994).

There is still a lack of data on risk factors for musculoskeletal disorders for different joints typical of the manual meat cutting industry. Tasks in this sector that involve awkward body postures have a strong association with injuries, as workers often maintain static positions for specific members or are engaged in repetitive activities while performing tasks for long periods. Knowledge of these risk factors can be used to identify and control high-risk tasks before they develop into musculoskeletal disorders, especially in the design stage (for hand tools and workstations) when using biomechanical models (Vogel et al., 2013).

\subsection{Illness due to ergonomic aspects in slaughterhouses}

The proposal for working conditions provided for in the parameters that refer to ergonomic conditions is directed to aspects of service provision conditions. It is necessary that such aspects highlight states of comfort and quality in the factors related to work actions. To this end, the intentionality of searching for ergonomic risks focuses on understanding and studying how the employee has his / her time during working hours and, consequently, whether the employee presents favorable adaptations for his / her physical and mental health.

As Lemos (2016) reported, the International Labour Organization (ILO) understands ergonomy as applying human biological sciences and engineering resources and techniques to concern mutual adjustment between man and work, whose results can be measured as human efficiency and labor well-being. In this conception, it is necessary to expand resources that support the conditions necessary for the work process and the progress of regularity and well-being of employees. In short, ergonomic risks exist in workplaces that present situations which require excessive physical effort from the employee. These situations contribute to an inadequate posture, weight lifting, extensive work periods, repetition of actions, and emotional conditions, such as stress, nervousness, among others (Lemos, 2016).

The intensification of work is related to the rhythms of work and productivity and workloads, leading to the development of stress and other musculoskeletal disorders (Valeyre, 2004). All physical effort is increased, postures and movements become more painful or fatiguing, favoring accidents (Gollac, 2005). Musculoskeletal diseases are the most frequent: WRMD and RSI (Gandon et al., 2017). When there is a break between work cycles, operators usually anticipate work so that they can maintain 
control and maintain the pace, in addition to maintaining a margin for possible unforeseen events. The supervisors often consider these breaks as unproductive time, as in Taylorism, forcing the operator to accelerate work in a vicious circle (Askenazy, 2004).

According to Lemos (2016), studies that were predicted over the years quantify that companies related to slaughterhouses' activities cause, on average, a high rate of annual accidents. These actions could be avoided or minimized if there were management plans to propose better working conditions and improvements in the steps provided for in these scenarios.

The search for such expected impacts as improvements becomes the responsibility of employers, who aim to measure improvements in their employees' quality of service, minimizing negative impacts that may damage the companies. The correctness of these aspects, and the search for improvement, lead mainly to increased productivity for employees. Also, companies avoiding an unhealthy place is a strategy to improve production efficiency and a health matter. Other conditions that add up to ergonomic risks are strengthened in employees' apparatuses and materials during various processes inside the slaughterhouses. The handling of high-risk instruments, summing up the other factors, are items to stand out in the processes of evident risks (Lemos, 2016). According to Magro, Coutinho, Blanch, and Moré (2014), the overload generated by the process of intensifying work in the meat production sector contributes to the illness of workers, which, in turn, due to high productivity, generates more intensification work, thus creating a vicious cycle around this problem. Lemos (2016) stated that mental exhaustion, due to the durability of course load, also causes psychological damage. Since physical conditions already consume employees, the emotions can also be compromised due to tiredness and the need to have a predisposition towards skills that require strength.

Data pointed out in Sarda, Ruiz, and Kirtschig (2009) research strengthens the factors discussed so far, about the main ergonomic risks triggers provoked in practices associated to slaughterhouses, amongst them manifested: upper limb inadequate posture, torso, and head; execution of static work of upper limb and lower limbs; studies have shown causal links between postural load and osteomuscular lesion; strength-demanding tasks when manipulating products and/or using work tools; exclusively standing working positions in fixed places with limited space; permanent labor in cold places; continuous exposure to noise above $80 \mathrm{~dB}(\mathrm{~A})$; insalubrious conditions like humidity and biological agents exposure.

Thus, it is understood that when a company becomes aware of the need to invest in ergonomic aspects, it tends to present an increase in production in the way that an employee faces a more peaceful environment, with actions that do not involve risk and road condition practices, tending to measure the proposed results more largely.

\section{Final Considerations}

Quality of life processes is strictly linked to conditions that involve quality of work in how one is dimensioned. The conditions of the appropriate scenarios for the jobs are consolidated through laws that justify and insure their workers; however, the research showed that many spaces do not make this adaptation feasible and remain exercising their markets outside the margins of the laws' requirements. Damage can range from hearing loss, exposure to low temperatures, as well as noise, infectious or parasitic diseases from the animals' gastrointestinal tract, in addition to long journeys where work is performed standing up, in the same position, contributing to the risk of developing musculoskeletal diseases such as RSI and WRMD, culminating in a high rate of illnesses in companies in this segment. According to logic, the attempt to mitigate such conditions is established as a prudent action. Thus, the responsible managers must draw up a prevention plan so that there is greater security in the working conditions, which are excessively required from their employees.

\section{References}

Abrahão, J. I., \& Pinho, D. L. M. (2002). As transformações do trabalho e desafios teórico-metodológicos da Ergonomia. Estudos de Psicologia (Natal), 7(spe), $45-52$. 
Araújo, T. M., Sena, I. P., Viana, M. A., \& Araújo, E. M. (2005). Mal-estar docente: avaliação de condições de trabalho e saúde em uma instituição de ensino superior. Rev. Baiana Saúde Pública, 6-21.

Assunção, A. A. (2003). Saúde e condições de trabalho nas escolas públicas. Reformas educacionais na América Latina e os trabalhadores docentes: Autêntica.

Askenazy, P. (2004). Les désordres du travail: enquête sur le nouveau productivisme: Éditions du Seuil et La République des Idées.

Barzotto, P. C. Estudo de riscos ambientais na indústria frigorífica - processos abate frango. Monografia de Espcialização, Universidade Tecnológica Federal do Paraná, Curitiba, Brasil.

Costa, A. \& Von Humboldt, S. (2020). Spirituality and Chronic Diseases in the Older Adults - Exploratory Study in the Older Adults. Psicologia, Saúde \& Doença, 21(01), 69-74.

Cruz, R. M. \& Lemos, J. C. (2005). Atividade Docente, Condições De Trabalho E Processos De Saúde. Motrivivência, 0(24), 59-80.

Evangelista, W. L. (2011). Análise ergonômica do trabalho em um frigorífico típico da indústria suinícola do Brasil. Tese de Doutorado, Universidade Federal de Viçosa, Viçosa, Brasil.

Gandon, L. F. M., Ferraz, R. R. N., Pavan, L. M. B., \& Zaions, A. P. D. R. E. (2017). Redução das faltas e dos acidentes de trabalho com base na implementação de melhorias ergonômicas na linha de produção de um frigorífico gaúcho. Revista Eletronica Gestão \& Saúde, 8(1), 92-113.

Gollac, M. (2005). L'intensité du travail: Formes et effets. Revue économique, 56(2), 195-216.

Kilbom, Å. (1994). Repetitive work of the upper extremity: Part II - The scientific basis (knowledge base) for the guide. International Journal of Industrial Ergonomics, 14, 59-86.

Lancman, S. \& Sznelwar, L. I. (2004). Christophe Dejours: da psicopatologia à psicodinâmica do trabalho. In: Christophe Dejours: da psicopatologia à psicodinâmica do trabalho: Fiocruz.

Lachance, D. H., Lennon, V. A., Pittock, S. J., Tracy, J. A., Krecke, K. N., Amrami, K. K., Poeschla, E. M., Orenstein, R., Scheithauer, B. W., Sejvar, J. J., Holzbauer, S., DeVries, A. S., \& Dyck, P. J. B. (2010). An outbreak of neurological autoimmunity with polyradiculoneuropathy in workers exposed to aerosolised porcine neural tissue: a descriptive study. The Lancet Neurology, 9(1), 55-66.

Laurell, A. C., \& Noriega, M. (1989). Processo de produção e saúde: trabalho e desgaste operário: Hucitec.

Lemos, V. G. (2016). Avaliação de riscos ambientais no setor de desossa em um frigorífico de abate bovino. Monografia de Espcialização, Universidade Tecnológica Federal do Paraná, Curitiba, Brasil.

Lima, C. M. G., Nora, F. M. D., Seraglio, S. K. T., Silva, J. M., Marzoque, H. J., Santana, R. F., Verruck, S., \& Scussel, V. M. (2020). Antibiotic residues in honey: a public health issue. Research, Society and Development, $9(11), 1-31$.

Magro, M. L. P. D., Coutinho, M. C., Blanch, J. M., \& Moré, C. L. O. O. (2014). Intensificação e prolongamento da jornada de trabalho nas indústrias de abate e processamento de carnes e seus impactos na saúde dos trabalhadores1. Cadernos de Psicologia Social Do Trabalho, $17(1), 67$.

Marzoque, H. J., Lima, C. M. G., Pagnossa, J. P., Cunha, R. F., Silva, D. R. G., Ramos, A. L. S., \& Ramos, E. M. (2020). Evaluation of pH in swine cascasses regardin on the transport distance of the animals: a case study. Research, Society and Development, 9(10), e6379108893.

Másculo, F. \& VidaL, M. C. (2013). Ergonomia: trabalho adequado e eficiente: LTC.

Matias, M. C. M., \& Abib, J. A. D. (2007). Sociedade em transformação: estudo das relações entre trabalho, saúde e subjetividade: EDUEL.

Melamed, S., Fried, Y., \& Froom, P. (2004). The joint effect of noise exposure and job complexity on distress and injury risk among men and women: The cardiovascular occupational risk factors determination in Israel study. Journal of Occupational and Environmental Medicine, 46(10), 1023-1032.

Mendes, L., Santos, H. B. dos, \& Ichikawa, E. Y. (2017). Health and Safety at Work: Analysis from the Brazilian Documentary Film Flesh and Bone. Safety and Health at Work, 8(4), 347-355.

Mi, B., Liu, G., Zhou, W., Lv, H., Liu, Y., Wu, Q., \& Liu, J. (2017). Platelet rich plasma versus steroid on lateral epicondylitis: meta-analysis of randomized clinical trials. Physician and Sportsmedicine, 45(2), 97-104.

Murcia, D. A. J., \& Martinez, M. S. C. M. (2016). Diagnóstico y diseño preliminar del programa de seguridad y salud en el trabajo en la empresa frigorífico de Zipaquirá. Proyecto Curricular de Ingeniería Industrial, Universidad Distrital Francisco José de Caldas, Bogotá, Colômbia

O'Sullivan, L. W., \& Gallwey, T. J. (2005). Forearm torque strengths and discomfort profiles in pronation and supination. Ergonomics, 48(6), 703-721.

Ranney, D. (2000). Distúrbios osteomusculares crônicos relacionados ao trabalho: Roca.

Rocha, J. C. D. S. (2002). Direito ambiental do trabalho: mudanças de paradigma na tutela jurídica à saúde do trabalhador: Editora LTr.

Rodrigues, M. A., \& Lenza, C. P. (2018). Direito ambiental esquematizado: Saraiva.

Saliba, T. M. (2018). Curso básico de segurança e higiene ocupacional: Editora LTr.

Sarda, S. E., Ruiz, R. C., \& Kirtschig, G. (2009). Tutela jurídica da saúde dos empregados de frigoríficos: considerações dos serviços públicos: [revisão]. Acta Fisiátrica, 16(2), 59-65. 
Research, Society and Development, v. 10, n. 1, e55310111980, 2021

(CC BY 4.0) | ISSN 2525-3409 | DOI: http://dx.doi.org/10.33448/rsd-v10i1.11980

Suárez, Y. (2015). Estudio de las condiciones de trabajo em la empresa frigorífico el pão, C. A., Umbicada em ele sector 19 de abril, Turmero, Estado Aragua. Tesis de Maestria, Universidad de Carabobo, La Morita, Venezuela.

Torres, A. V. (2002). Efectos del ruido en los trabajadores de la Industria Frigorífica. Ingeniería, 7(2), 90-96.

Valeyre, A. (2004). Les nouvelles formes d'intensification du travail industriel: logiques technologiques, organisationnelles et économiques. Économies et sociétés. Série AB, Économie du travail, ISMEA.

Vogel, K., Karltun, J., Eklund, J., \& Engkvist, I. L. (2013). Improving meat cutters' work: Changes and effects following an intervention. Applied Ergonomics, 44(6), 996-1003.

Wisner, A. (1994). A inteligência no trabalho: textos selecionados de ergonomia: Fundacentro. 